\title{
The factors affecting inter-organizational relationship success in Vietnam tourism sector
}

\section{Nguyen Thi Minh Phuong ${ }^{\text {abc }}$, Mai Ngoc Khuongab* and Nguyen Ngoc Duy Phuongab}

${ }^{a}$ School of Business, International University, Ho Chi Minh City, Vietnam

${ }^{b}$ Vietnam National University, Ho Chi Minh City, Vietnam

cDepartment of Tourism, Hong Bang International University, Vietnam

\section{H R O N I C L E \\ A B S T R A C T}

Article history:

Received: November 18, 2020

Received in revised format:

December 282020

Accepted: January 18, 2021

Available online:

January 18, 2021

Keywords:

Transaction Cost Theory

Inter-organizational relationship

Vietnam Tourism

Travel Company

Relationship Marketing
This study analyzed the factors influencing the effectiveness of inter-organizational relationship (IOR) through relationship marketing of travel companies with their partners based on data collection with 256 responses who were working for travel companies in Vietnam. The study used a quantitative approach as factor analysis, multiple regressions and path analysis. The results indicated that inter-organizational relationship effectiveness was directly and indirectly affected by coordination, trust, frequency of interaction, commitment, communication, organizational compatibility, and relationship marketing. Surprisingly, formalization did not significantly affect the effectiveness of IOR and relationship marketing. This study is an essential reference for managers to make decisions and to enhance the effectiveness of their collaborative partnerships.

(C) 2021 by the authors; licensee Growing Science, Canada

\section{Introduction}

Vietnam tourism possesses rich natural, historical and cultural heritage. Besides, it has over 3,000 km of coastline, pristine beaches, mountainous highlands, and dynamic growing cities. Based on Vietnam Tourism Annual Report 2019, in recent years, Vietnam tourism has developed, achieved success, and been called "World's Leading Heritage Destination"; "World's Best Golf Destination"; “Asia’s Leading Destination"; “Asia’s Leading Cultural Destination”, and "Asia's Leading Culinary Destination" (vietnamtourism.gov.vn, 2020). Furthermore, the total tourism receipts in 2019 is about 775 thousand billion VND; in 2018 is about 620 thousand billion VND; in 2017 is about 541 thousand billion VND (vietnamtourism.gov.vn, 2020). To have these successful achievements, thanks to the large efforts from all stakeholders of tourism sectors. However, 2020 was the hard time caused by breaking out the corona virus disease (Covid-19), which seriously impacted on Vietnam tourism, aviation, and many other industries. To escape from this situation, continuous effort should be invested in developing "tourism into a key economic sector", one of the priorities is increasing the awareness of the cooperation and coordination of the interorganizational relationships among the relevant tourism partners for providing better and safer tourist products and services. For that purpose, the travel companies require the relationship marketing to connect and exchange issues related to product development, marketing, communication, quality service provision, hotels, cruise ships, airline tickets, home-stay, share resources to minimize costs, etc. According to Cummings (1991), a good relationship does not happen by itself, therefore, each stakeholder must be actively involved in building good relationships. Other authors defined that inter-organizational relationships help firms create value by combining resources, sharing knowledge and information, increasing speed to market (Palmatier et al., 2007; Cropper et al., 2008; Agostini \& Nosella, 2015; Bierman \& Koops, 2017). Hodge and Anthony (1998) stated that an organization may form relationships with other organizations to reduce uncertainty and to gain better management over the features for the organization's survival are critical of the macro environment. Furthermore, Galaskiewicz (1985)

* Corresponding author.

E-mail address: mnkhuong@hcmiu.edu.vn (M. N. Khuong) 
found that the environmental uncertainty is the opportunity that prompted managers to seek out inter-allied administrators who had similar qualifications to them.

Recently, there have been many investigators examining the aspects of IOR to understand and improve its effectiveness. Many factors have been found as determinants of IOR effectiveness such as commitment, trust, dependence, relational norms, and transaction cost economics (Hibbard et al., 2001; Palmatier et al., 2006). Moreover, Mohr et al. (1994) found some key factors of IOR effectiveness including commitment, trust, coordination, interdependence, and the behavioral communication involves the quality communication, information exchange, and participation of partners in decision-making. Gummesson (2017) and Larentis et al. (2018) found that the motives for firms to establish the relationships with partners are relationship marketing, business success, trust, communication, etc... In addition, the main motivation to set up the inter-organizational relationship is to get benefits from their partners. Despite inter-organizational relationship was very popular in the scientific research world, however, it is not now well-known in the Vietnam tourism context, yet. So, the studies to find out which factors have a direct, indirect effect on the effectiveness of the inter-organizational relationship between travel companies and their business partners are still limited.

This study used travel companies as focal organizations managing the relationships with their business partners. The purpose of this study is to analyze the factors influencing the effectiveness of the inter-organizational relationships through the mediation of the relationship marketing of the travel companies with their business partners. This study provides new insights into the factors influencing the IOR effectiveness and critical managerial recommendations to tourism sectors for better development and design of their business strategies. The outcomes could be a foundation for other researchers to implement the similar studies in other industries.

\section{Literature Review}

\subsection{Inter-organizational Relationship Effectiveness}

Inter-organizational relationship (IOR) effectiveness refers to the overall evaluative relationship. It is defined as the overall satisfaction from the participants to achieve the result of expectative performance. Nonetheless, IOR effectiveness has two different approaches. First approach of IOR effectiveness associate's participants with overall satisfaction. Satisfaction refers to an organization's positive experience depending on its participants' capability to obey rules and fulfill expectative performance (Van de Ven \& Ferry, 1980; Anderson \& Narus, 1990). Second approach of IOR effectiveness defined it as a quantitative measure of the mutual benefits coming from participants reap. Furthermore, the IOR effectiveness based on how it fully carries out the objectives that have been satisfied by their business partners (Narus \& Anderson, 1987).

Previous researchers have highlighted various aspects of IOR performance. Especially basing on the study of Palmatier et al. (2006) to understand the factors of effective IOR performance focus on commitment, trust, dependence, relational norms, and transaction cost economics (Hibbard et al., 2001). These perspectives have distinct main factors of IOR performance. According to Morgan and Hunt (1994), commitment, trust, "not power" or "dependence", are the key to promote well inter-organizational exchange "efficiency, productivity and effectiveness", and they also found that communication devotes trust and commitment in IOR performance. Moreover, Mohr et al., (1994) noted some key factors of IOR effectiveness. First, the attributive inter-organizational relationship includes commitment, trust, coordination, and interdependence. Second, the behavioral communication involves the quality communication, information exchange, and participation of partners in decisionmaking. Finally, the techniques used to resolve conflicts between firms in business (Palmatier et al., 2006; Gummesson, 2017; Larentis et al., 2018) including relationship marketing, business success, trust, communication are the keys. In addition, the main motivation to set up the inter-organizational relationship is to get benefits from their partners. Besides, these authors found that "the factors of trust and communication indirectly have a negative small effect on IOR effectiveness through relationship marketing".

\subsection{Relationship Marketing}

The early marketing theory branched from economic theory. Blair et al. (1976) adapted marketing theory points out that "humans behave in a rational effort to maximize economic utility". In all economic contexts, the relationship marketing benefit expects to get corporate performance. Based on the study of Van de Ven, Andrew (1976) showed that "the final goal of firms were very strongly implicated in an inter-organizational relationship with other partners to achieve their goals, which organizations cannot achieve these goals alone". The literature on relationship marketing has highlighted several views as" attracting, maintaining and in multi-service firms enhancing customer relationships" defined by Berry (1995). Moreover, Berry and Parasuraman (1991) propose that "relationship marketing concerns attracting, developing, and retaining customer relationships." In the industrial marketing area, as Jackson (1985) defined relationship marketing as "marketing oriented toward strong, lasting relationships with individual accounts." In 1988, Paul used Jackson's view in the health care marketing area. Relationship marketing has been reported by Aijo (1996) point out that "a dynamic process with continuity as an important objective. According to Cova and Cova (2002) notes relationship marketing "aims at creating and developing a relation between the brand or the firm (even a member of the firm) and a customer, the brand community approach to marketing prefers to recreate and support the relation between customers. The communal interrelations exert pressure on members to remain 
loyal to the collective and consequently to the brand". Moreover, relationship marketing includes "the processes of interaction and engagement to maintain long-term cooperative relationships with mutual benefits among the parties" (Palmatier, 2008). It was also found that "supports all marketing activities directed toward establishing, developing, and maintaining successful" (Morgan and Hunt, 1994; Srinivasan and Moorman, 2005). And the relational exchanges-constitutes is a major shift in marketing theory. Payne and Frow (2017) showed that relationship marketing seems very important if the relationships are considered to be complex and it has multifaceted, as we know that inter-organizational relationships are complex. Its purpose is to generate long-term benefits relationships between their business partners (Miquel-Romero et al., 2014). Furthermore, it emphasized the present of trust, commitment and cooperation that based on the evident what has been promised, constant information exchange, reliability on what is being made, to be willing to solve problems (Palmatier et al., 2006; Gummesson, 2017; Larentis et al., 2018).

\subsection{Frequency of interaction}

Hall et al. (1977) published a paper in which they described frequenting of interaction is "related to high levels of the coordinate efforts and give information to each partner, as the level of contacts or exchange resources among organizations". To have an effectiveness of IOR requires a good indexes of frequency interaction such as quality of exchange resources (send guests to their partners), arrange programs, plan and join tasks together, focus on meeting the strategy as well as their outputs (Gawrich, 2006). Furthermore, the studies of Palmatier et al. (2006) indicated that the frequency of interaction affects highly on trust, it meant the frequency interactions give "their partners more accurate information, reduce uncertainty about future behaviors, and improve trust, even if they have no effects on their partner's satisfaction with or desire to maintain the relationship". So, the established relationship between two or more companies may agree to perform a specific program or a project in a short time or a long time that depends on their frequency of interactive relationship. Considered by Biermann (2008), the frequency of interaction is a duration, and intensity of interaction among organizations, which is a very significant index to measure the IR effectiveness. Drawing on the phenomenon of frequency of interaction among organizations demonstrated by Klijn (2008), Varwick and Koops (2009); and Reinalda (2009), four characteristics are "regular intense contacts; formal and informal rules of behavior; regular channels of cooperation of varying formalization; and final characteristic is long-term orientations as opposed to ad hoc cooperation". Moreover, the good interactive relations among the head of executives are very special for creating and maintaining inter-organizational relationships. Jones and Lichtenstein (2008) also agreed to this statement, showing that the inter-organizational relationship was established to carry out the projects in a period and this relationship only exists at this time, after finishing these projects or their goals, and these relationships will be disbanded. Furthermore, research by Casey et al. (2008) concluded that interactions between members, organizations were limited due to lack of partnership strategy to align initiatives and ineffective communication mechanisms. In addition, the results of interaction came from actions and reactions, carried out by participants who play active roles (Tadajewski and Saren, 2009; Larentis et al., 2018).

\subsection{Commitment}

Commitment refers to "typically the notion of connotes solidarity and cohesion", however this typically the notion of commitment is vague. According to Dwyer et al. (1987) expresses commitment is the highest period of relationship and defined clearly in the study" developing buyer-seller relationships" show three elements can be used to measure as" inputs, durability, and consistency" (Scanzoni, 1979). A great deal of previous research into commitment has focused on inter-organizational relationship durability abet continued effective exchange resources. Previous research has shown that commitment towards the inter-organizational relationship is defined as the worthiest of organizations "effort to maintain the relationship" (Morgan and Hunt, 1994). A study by Ganesan and Hess (1997) the topic entitled "Dimensions and Levels of Trust: Implications for Commitment to a Relationship" showed that "trust is generating increased interest in marketing and organizational studies", and their results indicated that trust in a sales representative (interpersonal credibility) is more strongly related to commitment than trust in an organization (organizational credibility). In contrast, trust based on organizational benevolence is a stronger predictor of commitment than interpersonal benevolence (Ganesan and Hess, 1997). In marketing, Morgan and Hunt (1994) suggested that "trust along with commitment are the main factors to cooperative behaviors essential for the success of interfirm alliances and an enduring desire to maintain a valued relationship: effective, behavioral, obligation, and normative commitment" (Jab and Ganesan, 2000). In fact, Anderson and Weitz (1992) defined commitment as "a relationship entails a desire to develop a stable relationship, a willingness to make short-term sacrifices to maintain the relationship, and a confidence in the stability of the relationship". Researchers attempted to evaluate the impact of commitment towards the "relationships between hotel companies and travel agents with the highest levels of partners' commitment are expected to be the most successful". This commitment got a positive effect on both "overall success" and satisfaction with travel agent marketing support, defined by Medina-Munoz and García-Falcón, (2000). Many recent studies (Cannon and Homburg, 2001; Palmatier et al., 2007) have shown that the committed party believes to obtain benefits and be stable from this long-term relationship. So, the tourism service companies can take these advantages to reduce transaction cost and lessen uncertainty in the environment. The efficient collaboration through long-term and committed relationships will help a company gain deeper knowledge of exchange partners' needs and thus facilitate access to valuable resources for the successful development and marketing of new service offerings and processes (Shah et al., 2006; Bell and Eisingerich, 2007). 


\subsection{Trust}

Trust refers to the belief in their business partners who will perform perfect commitments (Anderson and Weitz, 1992). There were many studies that investigated trust in inter-organizational relationships because trust was considered to be an important outcome factor of inter-organizational relationships. Similar work pursued by Zaheer et al. (1998) stated that trust is an index of inter-organizational relationship for evaluating their business partners. The literature on inter-organizational trust has highlighted several reflections that inter-organizational relationship agreements are honest and satisfied commitments by Anderson and Narus (1990). In the case of inter-organizational trust only exists when the relationships were established and should have enough procedure to make sure of the correct negotiating policy. At the same time the inter-organizational relationship is created, this informal and friendly atmosphere of faith in their business partners should keep this relationship alive and develop it to make sure of a long term and effective relationship (Morgan and Hunt 1994; Mohr and Spekman, 1994). According to Moorman et al. (1992), inter-organizational trust is ready to depend on their exchange partner who they trust. The results of trusting are based on the partner's competence and abilities such as "the required expertise to perform the job effectively and reliably". Moreover, it was based on the beliefs the partners who have intentions and beneficial motives to create this relationship when they see this as a new opportunity arise, which was not performed a commitment before, because the effectiveness of IOR depends on these participants trusting each other and carry out their goals (Medina-Muñoz et al., 2000). Then, Tsai et al. (2012) adapted these researchers' ideas, suggesting that trust as the perceived ability and willingness of the other party to behave in ways that considers the interest of both parties in the relationship.

\subsection{Co-ordination}

According to Mulford and Rogers (1982), coordination is also a process, in which organizations establish or accept existing decision rules to solve their shared task environment. Furthermore, coordination is a process that is all participation in the inter-organizational relationship search for playing the game together in a shared endeavor (Narus and Anderson, 1987). The work in this area is ongoing and varied. According to Stern and El-Ansary (1992) notes that the coordination is very meaningful in alliances with the agent of allocation. Moreover, the travel companies' attempts to coordinate with their business partners such as transportation companies, accommodation, restaurants, tourist attractions, these efforts include many specific actions like sending their business partners with up-to-date and timely information on each of the aspects influencing interorganizational relationship efficiency for example reservation; corporate discount rate; booking tours; free vouchers, tours upgrades, weekend tours, and activity awards. Besides, their business partners have to provide prices, rooms available, touring cars available, airline's ticket or train ticket available and sales promotions. A study by Morgan and Hunt (1994) showed coordination as a positively associated element in the effectiveness of IORs and demonstrated the highest levels of coordination in the activities carried out by inter-organizational relationship participants. Similarly, Mohr and Spekman (1994) have suggested that per partners look forward to the other to carry out their duties perfectly. In addition, Kumar and Nti (1998) showed that "Inter-organizational coordination ensures efficient alliance governance and greater transaction legitimacy among partners". Moreover, this issue has been considered by recent work of Medina-Muñoz et al. (2000) that "coordination are the activities with their partners are well-coordinated, and they plan and schedule the sales with the partners". Finally, Schreiner et al. (2009) stated that inter-organizational coordination aims to identify and build consensus about task requirements in a given alliance, the nature of the associated interdependence between partners, and the specification of working procedures for task execution.

\subsection{Communication}

There is a growing body of literature that recognizes the importance of communication. Medina-Muñoz et al. (2000) proposed that the communication is "timely, accurate, adequate, complete, and credible". The existing literature on inter-organizational communication is extensive and focuses particularly on sharing timely meaningful information in both formal and informal ways between organizations (Anderson and Narus, 1990). Likewise, Morgan and Hunt (1994) confirmed that communication in the relationship based on the major supplier keeps informed of new developments and then shares information to the partners. And the other element of influence in this relationship is that the communication should impart well to partners' expectations for inter-organizational relationship performance. Recent evidence suggests that the communication among partners is "transparent and especially timely communication" (Moorman et al., 1993). As Gyenes (1991); Mohr and Spekman (1994) proposed that the more successful the relationship will be, the more efficient the communication between partners is. On the other hand, Mohr and Nevin (1990) argued that the problems and conflicts among participants happened because of difficulty in communication. Similarly, Waddock (1988) emphasized that the communication and feedback are very significant because it is accurate to send information coming in time to make sure the difficult circumstances are solved quickly. The partners' ideas are very necessary to solve the important problems. Study of Etgar (1979) points out that the outcomes of the inefficient inter-organizational communication caused the conflicts, misunderstand, and produce disappointed.

\subsection{Formalization}

As far as formalization is concerned, Scott and Davis (2015) illustrated formalization is the degree of penned rules, procedures, and instructions. Similarly, Lee et al. (2015) found formalization is the degree of rules to control communications, decisions, 
procedures, roles, and norms (Olson et al., 2005; Kabadayi et al., 2007). As Briscoe (2007); Simon (2013) notes the procedures guide action to facilitate the effective work coordination. Furthermore, Hofmann and Jones (2005); Rockart and Mitchell (2009) showed that numerous factors affecting formalization such as reliable, efficiency, consistent performance, and speed that provides some distinct competencies for organizations. There is a different finding of formalization based on Vlaar et al. (2006) implementing tasks by connecting with outcomes such as make a contract, give rule, and have a procedure. On the other hand, based on research of Buvik and Reve (2001) confirmed again about formalization is the degree of rules to recognize the roles of firms, relationship of authority, procedures, norms, communications, and sanctions. Vlaar et al. (2006) wrote that the structure of formalization is the relationship and engagement between participants to understand their partners during workings in the collaborative contexts, and these activities were embedded together. Bucklin and Sengupta (1993) emphasized that the formality reflects the degree of an agreement depend on the highly identify the requirements. In addition, Dahlstrom and Nygaaard (1999) formalization refers to the level of ethical rules and establish standard behavior are formulated, along with the degree of role authorities are recommended.

\subsection{Organizational Compatibility}

Organizational compatibility is considered to be a similar domain and compatibility goal that has been found to enhance the effectiveness of inter-organizational company (Van De Ven \& Ferry, 1980). In fact, inter-organizational compatibility refers to the sharing of common experiences, values, principles, and business strategies between business partners (Kanter, 1994). Similarly, Bucklin and Sengupta (1993) emphasized that organizational compatibility has the same goals, business philosophies and corporate culture. In addition, other researcher has highlighted various aspects of organizational compatibility such as the partners have the comparable products and services, which have the same goals and cultures to achieve easily successful in inter-organizational integration and business to business relationship (Rich, 2003). The compatibility is able to create when they work together from existing work practices, and they get values from the business partners (Karahanna et al., 2006). In the relationship is easy to share the business information across their business partners (Sarkar et al., 2001; Ngai \& Huilin, 2010).

Basing on the literature review and previous researches mentioned above, the hypotheses are proposed:

$\mathbf{H}_{1}$ : Factors of coordination, trust, organizational compatibility, communication, formalization, commitment, and frequency of interaction have a positive impact on relationship marketing.

$\mathbf{H}_{2}$ : Factors of relationship marketing, coordination, trust, organizational compatibility, communication, formalization, commitment, and frequency of interaction have a positive impact on the effectiveness of IOR.

$\mathbf{H}_{3}$ : The effectiveness of IOR impact directly and indirectly on coordination, trust, organizational compatibility, communication, formalization, commitment, and frequency of interaction through relationship marketing.

\section{Methodology}

\subsection{Sample and data collection}

The target population for this study includes travel companies in Vietnam; these travel companies have various relationships with their business partners (i.e., accommodation, restaurants, bars, transport companies, tourist destinations). The travel companies have participated in inter-organizational relationship with their business partners and the main informants from these travel companies are managers, vice manager, manager of marketing and R \& D, vice manager of marketing and R \& D, and staff of marketing and R \& D. In terms of determining sample size of the study. According to Hatcher (1994, p. 73); Gorsuch (1983, p.332); Osborne and Costello (2004) suggested that the smallest theme to item ratio of observe variables at least 5:1. It means "the sample size should be at least five times of observe variables". This research consists of 39 observe variables. The required at least of responses for this study are 195 samples $(39 \times 5)$.

\subsection{Measures}

The questionnaire was built based on literature review from previous studies. First, Relationship marketing was developed by Morgan and Hunt (1994); Palmatier et al. (2006). Then, coordination was adapted from Narus and Anderson (1987); Morgan and Hunt (1994); Mohr and Spekman (1994); Medina-Munoz et al. (2000). Next, trust was borrowed from Anderson and Narus (1990); Mohr and Spekman (1994); Medina-Munoz et al. (2000); Palmatier et al. (2006). Variable of communication was adapted from Anderson and Narus (1990); Mohr and Spekman (1994); Medina-Munoz et al. (2000). Then, commitment was assessed from Mohr and Spekman (1994); Medina-Munoz et al. (2000); Palmatier et al. (2006). In addition, frequency of interaction was elicited by Gawrich (2006); Palmatier et al. (2006); Varwick and Koops (2009). Formalization was achieved from Bresser (1988); Bucklin and Sengupta (1993). Finally, organizational compatibility was elicited by (Van De Ven and Ferry, 1980). All of the questions were formulated on a five-point Likert-scale ranging from 1 to 5, equivalent to strongly disagree, disagree, neutral, agree and strongly agree respectively, except for the first question, "How often does your company interact with your travel partners?" in which $1=$ not at all, $2=$ seldom, $3=$ sometimes, $4=$ often, $5=$ very often, To increase the reliability and validity of all scales of this study we consulted experts to develop the questionnaires and through the semistructured interviews with five travel companies to pretest the questionnaire for consistency and clarity. Then, we adjusted 
the ambiguous words, phrases and questions to reach the highest level of clarification. The final questionnaire was established and delivered to 256 representatives of travel companies in different ways like through email, enclosed with postage paid envelopes, face to face, and online surveys. We sent a cover letter to invite them to participate our surveys, and we added a link to the online questionnaire to participants.

\section{Empirical data and analysis}

\subsection{Profile of sample}

About the sample characteristics, based on the descriptive analysis there were 256 answers received, one half of total respondents was staffs in charge of marketing and market development, 18 managers, 24 vice managers, 47 managers of marketing and $R \& D$ and 25 vice managers of marketing and R\&D. The results of company size, there were only 19 companies ( $7.4 \%)$ has been employed 51 to 100 staffs; 21 travel companies reporting for $8.2 \%$ of total sampling companies, which were employing more than 100 employees, are large ones. Nearly half of the companies (110 companies, accounting for 43\%) were employing from 10 to 50 employees; 82 companies (32\%) were recruiting only less than 10 employees. Regarding location of travel companies in Vietnam, there were 134 travel companies were located in the central, reporting for 52.3\% and remaining was 122 travel companies in the south, standing for $47.7 \%$. As founded year of travel companies, there were 26 companies $(10.2 \%)$ were set up less than 2 years ago; 89 companies $(34.8 \%)$ have been doing the business from 2 to 5 years; 76 companies (29.7\%) has been doing the business from 5 to 10 years, and finally is 50 travel companies has doing business more than 10 years (19.5\%). This showed the fact that Vietnam tourism industry is young and growing industry. According to age of interorganizational relationship, 99 travel companies (38.7\%) have built the inter-organizational relationship with their partners, 63 travel companies $(24,6 \%)$ have a relationship from 5-10 years, 40 travel companies $(15,6 \%)$ are doing business with their partners more than 10 years.

\subsection{Reliability and validity of variables}

The core reliability was analyzed by primary component factor analyze. After that, Crobach's alpha was computed as a reliability test for the hypothesis. Multiple regression was employed to estimate the relationship between independent variables, mediating variables, dependent variables, and path analysis. The results present on Table 1 showed that Cronbach's alpha for all constructs have reliability range from .705 to .832 that indicated that the measures are internal consistent, the existing data are reliable and appropriated to principal components' analysis. According to Pallant (2020), the reliable factors must have Cronbach's alpha value of at least .60 or above.

\section{Table 1}

$\underline{\text { Summary statistics for measures-Reliability statistics }}$

\begin{tabular}{lcc}
\hline Construct & Number of Items & Cronbach's Alpha (N=256) \\
\hline EFOFIOR: Effectiveness of Inter-organizational Relationship & 4 & .765 \\
REMA: Relationship Marketing & 5 & .701 \\
COORD: Coordination & 4 & .832 \\
TRUSTIR: Trust & 4 \\
ORGCOM: Organizational compatibility & 4 \\
COMUNIR: Communication & 4 & .788 \\
FORMIR: Formalization & 4 & .781 \\
COMITIR: Commitment & 4 & .797 \\
FREINTER: Frequency of interaction & .810 \\
\hline *All items have factor loading $\geq 0.5 ;$ KMO index of dependent variables $=.795$ and Sig. of Bartlett's test $=.000 ;$ Total Variance Explained $=52.8 \%$; & .758 \\
KMO index of independent variables $=.881$ and Sig. of Bartlett's test $=.000 ;$ Total Variance Explained $=62.4 \%$.
\end{tabular}

\subsection{Factors affecting inter-organizational relationship effectiveness.}

Identifying which factors are associated with the effectiveness of inter-organizational relationship, this study used Pearson correlation to identify these factors. The findings of the correlational analysis present in Table 2 provided the correlation coefficients between the effectiveness of IOR and independent variables: coordination; trust; organizational compatibility; communication; formalization; commitment; frequency of interaction; relationship marketing. Based on Tabachnick and Fidell (2001), Pearson Correlation (r) is smaller than 0.7 will be retained. The highest Pearson correlation in this research was $r$ $=.613$ that was smaller than 0.7 , so all these factors were retained. There are positive and significant correlations between the effectiveness of IOR and eights independent variables. The strongest correlation between the variables is $r=.613$ (P $<.05$ ) between EFOFIOR and COORDIR. Next is $\mathrm{r}=.588(\mathrm{P}<.05)$ between EFOFIOR and TRUSTIR, followed by a correlation of $\mathrm{r}=.509(\mathrm{P}<.05)$ between EFOFIOR and COMUNIR. Then, FORMIR $(\mathrm{r}=.506, \mathrm{P}<.05)$; COMITIR $(\mathrm{r}=.504, \mathrm{P}<.05)$; FREINTER $(\mathrm{r}=.464, \mathrm{P}<.05)$; while the correlation between REMA and EFOFIOR is the lowest $(\mathrm{r}=.376, \mathrm{P}<.05$. It is concluded that the higher level of coordination, trust, communication, commitment, formalization, organizational compatibility, frequency of interaction, relationship marketing could lead to the higher level of EFOFIOR. 
Table 2

Correlation Matrix between Variables

\begin{tabular}{|c|c|c|c|c|c|c|c|c|c|}
\hline & EFOFIOR & 1 & 2 & 3 & 4 & 5 & 6 & 7 & 8 \\
\hline 1. COORDIR & .613 & 1.000 & & & & & & & \\
\hline 2. TRUSTIR & .588 & .528 & 1.000 & & & & & & \\
\hline 3. ORGCOM & .461 & .448 & .414 & 1.000 & & & & & \\
\hline 4. COMUNIR & .509 & .572 & .551 & .377 & 1.000 & & & & \\
\hline 5. FORMIR & .506 & .581 & .472 & .496 & .520 & 1.000 & & & \\
\hline 6. COMITIR & .504 & .319 & .493 & .309 & .426 & .322 & 1.000 & & \\
\hline 7. FREINTER & .464 & .387 & .309 & .358 & .318 & .285 & .228 & 1.000 & \\
\hline 8. REMA & .376 & .274 & .242 & .320 & .324 & .292 & .200 & .342 & 1.000 \\
\hline Mean & 3.917 & 3.693 & 3.696 & 3.606 & 3.842 & 3.881 & 3.918 & 3.748 & 3.503 \\
\hline Std. Deviation & .532 & .531 & .565 & .614 & .556 & .537 & .612 & .613 & .608 \\
\hline
\end{tabular}

Source: Authors

\subsection{Hypotheses testing}

\subsubsection{Factors affecting relationship marketing (REMA)}

Table 3 presents the testing results of hypothesis one and hypothesis two. First, we start with using REMA as dependent variable. Regarding ANOVA: F $(7,248)=8.586$; Sig. $=.000(\mathrm{p}<.05)$. In addition, $\mathrm{R}^{2}=.195$ showed that $19,5 \%$ relationship marketing can be explained by the model.

Table 3

Multiple regression coefficients analysis for $\mathrm{H} 1$

\begin{tabular}{lccc}
\hline Independent variables & Unstandardized coefficients (B) & t-value & Sig. \\
\hline (Constant) & 1.163 & 3.523 & .001 \\
COORDIR & -.019 & -.204 & .239 \\
TRUSTIR & -.020 & 2.083 & .811 \\
ORGCOM & $\mathbf{. 1 4 4}$ & $\mathbf{. 0 3 8}$ & $\mathbf{. 1 4 6}$ \\
COMUNIR & $\mathbf{. 1 8 2}$ & 1.066 & .322 \\
FORMIR & .093 & .287 \\
COMITIR & .022 & 3.448 \\
\hline
\end{tabular}

ANOVA: $F(7,248)=8.586 ;$ Sig. $=.000, p<.05 ;$ Model summary: $R^{2}=.195$

Source: Authors

There were three significant predictors among seven factors with significant value less than $0.05(\mathrm{P}<.05)$ have positive impacts on relationship marketing, which showed positive relationships between REMA and the predictors of ORGCOM with $\mathrm{B}=.144$ at Significant value is $.038(\mathrm{p}<.05)$; COMUNIR with $\mathrm{B}=.182$ at Significant value is $.033(\mathrm{p}<.05)$; FREINTER with $\mathrm{B}=.218$ at Significant value is $.001(\mathrm{p}<.05)$. These results showed that "1-standard deviation" increasing in the organizational compatibility, communication, and frequency of interaction will lead to the increase of score of .144;.182; .218 respectively in the relationship marketing, whereas alternative variables were maintained just as constant. The regression equation illustrated the relationship between dependent variables with independent variables was formulated as below:

Model 1: REMA $=1.163+.144$ ORGCOM +.182 COMUNIR +.218 FREINTER

\subsubsection{Factors affecting the effectiveness of IOR (EFOFIOR)}

Table 4 presents the testing results of hypothesis two. Using EFOFIOR as dependent variable. Based on ANOVA: F (8,247) $=42.272$, Sig. $=.000, \mathrm{p}<.05$. In addition, the $\mathrm{R}^{2}=.578$ indicated that $57,8 \%$ of effectiveness of IOR can be explained by relationship marketing, commitment, frequency of interaction, trust, coordination.

Table 4

Multiple regression coefficients analysis for $\mathrm{H} 2$

\begin{tabular}{|c|c|c|c|}
\hline Independent variables & Unstandardized coefficients (B) & t-value & Sig. \\
\hline (Constant) & .124 & .579 & .563 \\
\hline COORDIR & .275 & 4.716 & .000 \\
\hline TRUSTIR & .188 & 3.568 & .000 \\
\hline ORGCOM & .049 & 1.098 & .275 \\
\hline COMUNIR & .000 & -.005 & .996 \\
\hline FORMIR & .073 & 1.323 & .187 \\
\hline COMITIR & .188 & 4.422 & .000 \\
\hline FREINTER & .145 & 3.515 & .001 \\
\hline REMA & .098 & 2.444 & .015 \\
\hline
\end{tabular}

There are five factors among eight predictors have significant associated with EFOFIOR: relationship marketing $(\mathrm{B}=.098, \mathrm{P}$ $<.015)$; Commitment $(\mathrm{B}=.188, \mathrm{P}<.000)$; Frequency of interaction $(\mathrm{B}=.145, \mathrm{P}<.001)$; Trust $(\mathrm{B}=.188, \mathrm{P}<.000)$; Coordination $(\mathrm{B}=.275, \mathrm{P}<.000)$. These results suggest that relationship marketing, commitment, frequency of interaction, trust, 
and coordination had a direct effect on the effectiveness of IOR. It showed that "1-standard deviation" increasing in the relationship marketing, commitment, frequency of interaction, trust, and coordination will lead to the increasing of score of $.098 ; .188 ; .145 ; .188 ; .275$ respectively, in the effectiveness of IOR. The equation of the relationship between the independent variables and the dependent variable was formulated as below:

Model 2: EFOFIOR $=.124+.275$ COORDIR +.188 TRUSTIR +.188 COMITIR +.145 FREINTER +.098 REMA

\subsubsection{Total Causal Effects on the effectiveness of IOR}

Table 5 provides an overview the total direct and indirect effects of COORDIR; TRUSTIR; COMITIR; FREINTER; ORGCOM; COMUNIR; FORMIR; REMA on the effectiveness of IOR (Hypothesis 3). Based on Hayes and Preacher (2008) suggest the bootstrap method to check "the meaning of indirect effect or intervention". The results of bootstrapping is at confidence intervals level of $95 \%$. In the case a zero located in the interval range between the upper boundary (UL) and the lower boundary (LL), it is concluded that there is no indirect effect or intervention. In contrast, in the case there is a zero between the lower boundary and the upper boundary, it is concluded that there is significant indirect effect or mediation at confidence level of $95 \%$ (Preacher and Hayes, 2004).

Table 5

Direct, Indirect, and Total Causal Effects

\begin{tabular}{|c|c|c|c|c|c|}
\hline \multirow[b]{2}{*}{ Independent Variables } & \multicolumn{3}{|c|}{ Causal effects } & & \\
\hline & Direct & Indirect & Total & & \\
\hline COORDIR & .275 & --- & .275 & -.0185 & .0139 \\
\hline TRUSTIR & .188 & ---- & .188 & -.0178 & .0124 \\
\hline COMITIR & .188 & --- & .188 & -.0092 & .0145 \\
\hline FREINTER & .145 & .022 & .167 & .0054 & .0417 \\
\hline ORGCOM & ---- & .014 & .014 & .0015 & .0319 \\
\hline COMUNIR & ---- & .178 & .178 & .0020 & .0397 \\
\hline REMA & .098 & ---- & .098 & ---- & ---- \\
\hline Total & 0.894 & 0.214 & 1.108 & & \\
\hline
\end{tabular}

\section{Discussions of findings}

Source: Authors

In order to discuss and respond the questions which of the seven independent variables (coordination, trust, organizational compatibility, communication, formalization, commitment, and frequency of interaction) and the mediating variable (relationship marketing) significantly affect the dependent variable (the effectiveness of IOR), the literature review from prior studies noted the effectiveness of IOR is determined by the effect of coordination, trust, organizational compatibility, communication, formalization, commitment, and frequency of interaction on relationship marketing.

The first empirical result has confirmed that coordination has a positive impact directly on inter-organizational relationship of effectiveness, coordination provided the largest set of significant with beta value $(\mathrm{B}=.275, \mathrm{p}<.001)$, was considered the most important factor. This indicates that COORDIR was the factor that had the most effect on the effectiveness of IOR. This finding supports the theory proposed by Narus and Anderson, (1987); Morgan and Hunt, (1994); Mohr and Spekman, (1994). These authors suggested that coordination is a positively associated with successful inter-organizational relationship because of the highest level of coordination carried out in the activities by their partners, and also look for working together in the highest effort to achieve their goals that rely on tasks of each partner. They hope inter-organizational relationship participants to perform well these tasks (Medina-Muñoz et al., 2000; Schreiner et al., 2000).

Secondly, the commitment has directly influenced on the effectiveness of IOR with $(\mathrm{B}=.188, \mathrm{p}<.001)$. This finding has provided a significant contribution to IOR of effectiveness in Vietnam tourism context, and indicated the more commitment parties involved in IOR, the higher relationship effectiveness is. This finding is consistent with that of Morgan and Hunt (1994) have found that commitment is a key to "cooperative behaviors essential for the success of inter-firm alliances". This result reflects those of Anderson and Weitz, (1992); Morgan and Hunt, (1994); Medina-Muñoz, et al. (2000) who also found that "make an effort to maintain the relationship, have a strong sense of loyalty to partners". The more successful IOR of travel companies have, the highest level of commitment put into the relationships are.

Thirdly, trust $(\mathrm{B}=.188, \mathrm{p}<.001)$ has a direct impact on the effectiveness of IOR. It's true in the reality of Vietnam tourism industry, the highest level of trust to each other, the longer of maintaining relationships with partners are. This relationship enables the travel companies' trust and honesty are at the core of good management practices, and this is an essential background for the effectiveness of IOR and vice versa. This finding was also supported by suggestion of Anderson and Narus (1990), Medina-Munoz et al. (2000,) and Mohr and Spekman (1994), Palmatier et al. (2006) who also found that "trust and honesty are at the core of good management practices which are a necessary requirement to developing a partnership relation- 
ship; trust is also a procedure indicator for evaluating inter-organizational relationship, they have established inter-organizational relationships with the purpose of building trust before allowing organizations and the managers can work together to create the final results.

The fourth empirical result has confirmed that frequency of interaction $(B=.145, \mathrm{p}<.001)$ has positively impacted direct on the effectiveness of IOR, besides that frequency of interaction $(B=.022, p<.001)$ also has an indirect impact on EFOFIOR through relationship marketing, as well as it has direct positive effect on REMA $(B=.218, p<.05)$. These findings mean the highest level of frequency of interaction through relationship marketing, the most level of inter-organizational relationship effectiveness got. This finding was supported by Gawrich (2006), found that "frequency of interaction is able to be an indicator for a strong inter-organizational relationship, the quality of exchanges, the level of preparation and participation, and the strategic focus of meetings as well as their output is crucial inter-organizational relations may vary in terms of duration". This study supports evidence from previous observations (Hall, et al., 1977; Palmatier et al., 2006; Varwick and Koops, 2009; Reinalda, 2009; Klijn, 2008) defined as "the higher levels of coordinate efforts and give information; regular intense contacts; formal and informal rules of behavior; regular channels of cooperation of varying formalization; and orientations as opposed to cooperation".

The fifth empirical result has confirmed that communication has a direct effect on REMA $(\mathrm{B}=.182, \mathrm{p}<.05)$ and $(\mathrm{B}=.178, \mathrm{p}$ $<.001)$ has a positive indirect impact on the effectiveness of IOR through relationship marketing. This result was supported by Morgan and Hunt (1994) point out that "it's supporting all marketing activities directed toward establishing, developing, and maintaining successful relationships". Similarly, Mohr and Spekman, (1994) show that "the more successful of the relationship will be when the communication between partners is more efficient". There are similarities between the attitudes expressed by communication in this study and those described by Anderson and Narus, (1990); Morgan and Hunt, (1994) indicated that "communication should impart well to partners' expectations for inter-firm's performance, keep informed of new developments, and share timely meaningful information in both formal and informal ways between organizations". Similarly, Moorman et al. (1993); Medina-Muñoz et al. (2000) also found that "the communication with the travel agent is timely, accurate, adequate, complete, and credible".

The sixth empirical result has confirmed that organizational compatibility has positively impacted direct on REMA $(\mathrm{B}=.144$, $\mathrm{p}<.05)$ and $(\mathrm{B}=.014, \mathrm{p}<.001)$ has a positively indirect impacted on inter-organizational relationship effectiveness through relationship marketing. These results further support the idea of Van De Ven and Ferry (1980); Ruekert and Walker (1987); Rich (2003) who found that organizational compatibility is "firm's goals and objectives are consistent with the partner firm". In addition, Achrol et al. (1990) include strategic and cultural compatibility. Furthermore, Bucklin et al. (1993) showed that the partner matched similar in management style and company culture in which were chosen to create alliances. As well as having goals compatibility to achieve the effectiveness of IOR, practices, and getting values from the business partners (Karahanna et al., 2006).

The final finding has confirmed that relationship marketing has a positive direct effect on the effectiveness of IOR with (B $=.098, \mathrm{p}<.05$ ). This result agrees with those obtained by Palmatier (2008); Morgan and Hunt (1994); Blair et al. (1976) found that "relationship marketing supports all marketing activities directed toward establishing, developing, and maintaining successful relationships such as supporting posters, sign boards, brochures, leaflets, displays, advertisement to partners". Besides, getting benefit from "the results of public relation programs from partners, generate long-term benefits relationships between their business partners, and be willing to solve problems"(Miquel-Romero et al., 2014; Gummesson, 2017; Larentis et al., 2018). Surprisingly, in this current study there is no differences were found in formalization and EFOFIOR in the relationship in Vietnam tourism industry. There was not different significant between formalization and relationship marketing, either inter-organizational relationship effectiveness. Formalization didn't have positively impacted direct or indirect on the effectiveness of IOR (FORMIR at $\mathrm{B}=.073, \mathrm{P}=.187>.05)$ and on relationship marketing (FORMIR at $\mathrm{B}=.093, \mathrm{P}=.287$ $>$.05). These findings are rather disappointing because the empirical result hasn't confirmed any previous studies defined formalization is "rules, procedures, and instructions" (Buvik and Reve, 2001; Scott and Davis, 2006). This outcome is contrary to that of Vlaar et al., (2006) found that formalization have a positive effect in the relationship "make sense of their partners, the relationships in which they are engaged and the collaborative contexts in which these are embedded". In addition, Lee et al. (2015) defined formalization is "The degree to which rules govern decisions, roles, norms, procedures, and communications"(Olson et al., 2005; Kabadayi et al., 2007).

\section{Conclusions and implications}

The main goal of the study was to determine the effect of coordination, trust, organizational compatibility, communication, formalization, commitment, and frequency of interaction on relationship marketing and the effectiveness of IOR, and find out what factors have direct and indirect effect on the effectiveness of IOR. The findings showed that organizational compatibility (ORGCOM); communication (COMUNIR); frequency of interaction (FREINTER) have a different significant level and direct impact on relationship marketing. Another important finding was that coordination (COORDIR); trust (TRUSTIR); commitment (COMITIR); frequency of interaction (FREINTER); relationship marketing (REMA) have direct impacts on EFOFIOR. The most interesting finding was that FREINTER; ORGCOM; COMUNIR have a different significant 
levels and indirect impacts on EFOFIOR through REMA. The research has also shown that the proposed hypothesis about the direct-indirect effect of formalization on inter-organizational relationship effectiveness through relationship marketing didn't support, nonetheless the correlation coefficients (FORMIR at $\mathrm{r}=.506, \mathrm{P}<.05$ ) was positive and significant. It maybe explains this finding happened because of measurement for the factor of formalization was measured as the evaluation of the travel companies on the aspect of the clear prescriptions and distributions of tasks; apply ethical rules and standards; have clear routines and procedures for safety; all rules and regulations of the relationships are well - prescribed, so these measures maybe not suitable with this context, then in the future we should use other potential measurements. On the other hand, this result happened because the respondants didn't understand well the characteristics of formalization.

These findings suggest that in general identifying relationship marketing as a key mediating variable in inter-organizational relationship effectiveness is very important to Vietnam tourism industry's leaders to know that when they work in the interorganizational relationship, they can get many benefits from relationship marketing, so they should invest to boost marketing activities for both travel companies themselves and their business partners, first they should prioritize relationship marketing issues such as increase customer market, internal market, influence market, recruitment market, supplier market, referral market and so on. Then, they should boost the frequency of interaction in both formal and informal channels such as frequency keep in touch by email, phone, Facebook, fax, etc. In addition, they should help each other with other services such marketing, staff training, customer care, share information, send tourist to these business partners more often. Besides that, the travel companies should need tightening up a little in the effectiveness of IOR through relationship marketing to get many benefits such as special promotions, potential benefits include more sales from their business partners, appropriate commission levels, additional and improved promotional and advertising support by their business partners (i.e., accommodation, restaurants, bars, transport companies, tourist destinations). In addition, the travel companies receive promotional support such as posters, sign boards, brochures, leaflets, displays, advertisement at accommodation, at the airport and station, introduce tours to guests, etc from their partners. Therefore, they should be considered the main criteria helping tourism firms and governments to achieve higher levels of performance. The travel companies should speed up the coordination of activities such as having plan and schedule for services or delivery guests to partners, then the travel companies will get many benefits from their partners such as sales promotion (e.g., early booking discount, bulk booking, get corporate discount rate). Because of existing of inter-organizational trust in the long relationships were established and have well- coordinated procedure to make sure correct negotiating policies. For Vietnam tourism industry, pay more attention in improving coordination are encouraged. They should seat together to discuss, plan, schedule and contribute the opinions to build and deliver the best services and products to guests. An action planned for the tourism industry continue growing is a priority to help travel companies and government tourism agencies to secure competitive advantages to create appropriate environments that boost tourism development. We should focus on collaboration, tourism managers and policy-makers alike can apply better decision-making tools in attaining inter-organizational relationship by showing more commitment toward building and maintaining the relationships seriously such as finding trusty partners; keeping promises during doing business together. Moreover, they should build a good communication, official formalization, and organizational compatibility about the goals and objectives are consistent with their partners, and have similar organizational cultures, management styles, philosophies, and approaches to business dealings. Especially, to survive the travel companies should rely on support of their business partners and technology, which is the virtual staff such as the automatic consulting chatbot that can replace up to $80 \%$ of the basic telesales team's work, customer care. Meanwhile, customer relationship management by storing and exploiting customer data also support the tracking and management of the personnel working and selling online. Besides that, the travel companies should consider using automatic email marketing to maintain of the interaction with their business partner and keep in touch with the old guest's data in the case to streamline staff. In addition, the travel companies should design a professional web, which must be clear, beautiful pictures to attract clients to your posts on the website or on social networks that helps tourist easy to approach and book straightforward. Because we are in the digital age, the users have access to a huge information, so we should build a professional sales team for single-closing consulting and support sale tickets and help guest to book tours online, and guide for payment that must be easy and convenient payment. In order for customers to have a good impression of your services, the consultant must understand the products and keep a good attitude towards clients.

This study has some limitations. First, the proposed aspects and criteria were selected from existing studies; therefore, our discussion might not be comprehensive. Second, this study adopted the multiple regression to evaluate the examined aspects and confirmed these factors in Vietnam tourism industry. Finally, because this study focused on only survey travel companies, so the study's external generalizability is limited. Future studies should use data from both sides or explore qualitative approach by in-depth interview's travel companies' managers to address issues of generalizability. Detailed descriptions of literature review and theory remain scarce and future studies should enrich the literature by focusing on specific aspects of these factors and having theory application.

\section{References}

Aijo, T. (1996). The theoretical and philosophical underpinnings of relationship marketing: environmental factors behind the changing marketing paradigm. European Journal of Marketing, 30(2), 8-18.

Agostini, L., Filippini, R., \& Nosella, A. (2015). Brand-building efforts and their association with SME sales performance. Journal of Small Business Management, 53(sup1), 161-173. 
Anderson, E., \& Weitz, B. (1992). The use of pledges to build and sustain commitment in distribution channels. Journal of Marketing Research, 29(1), 18-34.

Anderson, J. \& Narus, J. (1990). A model of distributor firm and manufacturer Firm Working Partnerships. Journal of Marketing, 54(1), $42-58$.

Bell, S. J., \& Eisingerich, A. B. (2007). The paradox of customer education. European Journal of Marketing.

Berry, L. L., \& Parasuraman, A. (1991). Marketing Services (New York. NY: Free.

Berry, L. L. (1995). Relationship marketing of services - growing interest, emerging perspectives. Journal of the Academy of Marketing Science, 23(4), 236-245.

Berry, L. L. (1983). Relationship Marketing, in Emerging Perspectives on Services Marketing, L. Berry, G.L.Shostack, and G.D. Upah, eds. Chicago: American Marketing Association, 25-28.

Biermann, R., \& Koops, J. A. (Eds.). (2017). Palgrave handbook of inter-organizational relations in world politics. Palgrave Macmillan.

Biermann, R. (2008).Towards a theory of inter-organizational networking: The Euro-Atlantic security institutions interacting. Review of International Organizations, 3(2), 151-77.

Blair, E., \& Uhl, K. P. (1976). Wroe Alderson and modern marketing theory. BEBR faculty working paper; no. 0326.

Bresser, R. K. (1988). Matching collective and competitive strategies. Strategic Management Journal, 9(4), 375-385.

Briscoe, F. (2007). From iron cage to iron shield? How bureaucracy enables temporal flexibility for professional service workers. Organization Science, 18(2), 297-314.

Bucklin, L. P., \& Sengupta, S. (1993). Organizing successful co-marketing alliances. Journal of Marketing, 57(2), 32-46.

Buvik, A., \& Reve, T. (2001). Asymmetrical deployment of specific assets and contractual safeguarding in industrial purchasing relationships. Journal of Business Research, 51(2), 101-113.

Cannon, J. P., \& Homburg, C. (2001). Buyer-supplier relationships and customer firm costs. Journal of Marketing, 65(1), 29-43.

Casey, B. J., Getz, S., \& Galvan, A. (2008). The adolescent brain. Developmental Review, 28(1), 62-77.

Cova, B., \& Cova, V. (2002) Tribal marketing: The tribalisation of society and its impact on the conduct of marketing. European Journal of Marketing, 36(5/6), 595-620.

Dahlstrom, R., \& Nygaard, A. (1999). An empirical investigation of ex post transaction costs in franchised distribution channels. Journal of marketing Research, 36(2), 160-170.

Dwyer, F. R., Schurr, P. H., \& Oh, S. (1987). Developing Buyer-Seller Relationships. Journal of Marketing, 51(2), 11-27.

Etgar, M. (1979). Sources and types of intra-channel conflict. Journal of Retailing, 55(1), 61-78.

Galaskiewicz, J. (1985). Interorganizational Relations. Annual Review of Sociology, 11, 281-304

Ganesan, S., \& Hess, R. (1997). Dimensions and levels of trust: implications for commitment to a relationship. Marketing Letters, 8(4), 439-448.

Gawrich, A (2006). Die EU-Minderheitenpolitik und die Erweiterungsprozesse. Zeitschrift für Politikwissenschaft, 16(2), $491-508$.

Gorusch, R. L. (1983). Factor Analysis (2nd ed.). Hillsdale, NJ: Lawrence Erlbaum Associates.

Gummesson, E. (2017). From relationship marketing to total relationship marketing and beyond. Journal of Services Marketing, 31(1), 1619.

Gyenes, L. A. (1991). Build the foundation for a successful joint venture. Journal of Business Strategy, 12(6), 27-32. doi:10.1108/eb039452

Hall, R. H., Clark, J. P., Giordano, P. C., Johnson, P. V., \& Van Roekel, M. (1977). Patterns of interorganizational relationships. Administrative Science Quarterly, 22(3), 457-474.

Hatcher, L. (1994). A Step-by-Step Approach to Using the SAS ${ }^{\circledR}$ System for Factor Analysis and Structural Equation Modeling. Cary, N.C.: SAS Institutte, Inc.

Hibbard, J. D., Kumar, N., \& Stern, L. W. (2001). Examining the Impact of Destructive Acts in Marketing Channel Relationships. Journal of Marketing Research, 38(1), 45-61.

Hodge, B. J., Anthony, W. P., \& Gales, L. M. (1998). Teoría de la organización: Un enfoque estratúgico. Pearson Prentice Hall.

Hofmann, D. A., \& Jones, L. M. (2005). Leadership, collective personality, and performance. Journal of Applied Psychology, $90(3), 509$.

Jackson, D., \& Alexopoulos, N. (1985). Gain enhancement methods for printed circuit antennas. IEEE Transactions on Antennas and Propagation, 33(9), 976-987.

Jap, S. D., \& Ganesan, S. (2000). Control mechanisms and the relationship life cycle: Implications for safeguarding specific investments and developing commitment. Journal of Marketing Research, 37(2), 227-245.

Jones, C., \& Lichtenstein, B. B. (2008). Temporary inter-organizational projects. In The Oxford handbook of inter-organizational relations.

Kabadayi, S., Eyuboglu, N., \& Thomas, G. P. (2007). The performance implications of designing multiple channels to fit with strategy and environment. Journal of Marketing, 71(4), 195-211.

Kanter, R. M. (1994). Collaborative advantage. Harvard Business Review, 72(4), 96-108.

Karahanna, E., Agarwal, R., \& Angst, C. M. (2006). Reconceptualizing compatibility beliefs in technology acceptance research. MIS Quarterly, 30(4), 781-804.

Klijn, E.-H. (2008). Policy and Implementation Networks: Managing Complex Interactions. In: Cropper, S., Ebers, M., Huxham C. and Smith Ring, P. (eds.) The Oxford Handbook of Inter-organizational Relations, Oxford: Oxford University Press, 118-46.

Kumar, R., \& Nti, K. O. (1998). Differential learning and interaction in alliance dynamics: A process and outcome discrepancy model. Organization science, $9(3), 356-367$.

Larentis, F., Simone Antonello, C., \& Slongo, L. A. (2018). Organizational culture and relationship marketing: an interorganizational perspective. Revista Brasileira de Gestão de Negócios, 20(1).

Lee, J. Y., Kozlenkova, I. V., \& Palmatier, R. W. (2015). Structural marketing: Using organizational structure to achieve marketing objectives. Journal of the Academy of Marketing Science, 43(1), 73-99.

Medina-Muñoz, D., \& García-Falcón, J. M. (2000). Successful relationships between hotels and agencies. Annals of Tourism Research, 27(3), 737-762.

Miquel-Romero, M. J., Caplliure-Giner, E. M., \& Adame-Sánchez, C. (2014). Relationship marketing management: Its importance in private label extension. Journal of Business Research, 67(5), 667-672.

Mohr, J., \& Nevin, J. R. (1990). Communication strategies in marketing channels: A theoretical perspective. Journal of Marketing, 54(4), 36-51. 
Mohr, Jakki; Spekman, Robert (1994). Characteristics of Partnership Success: Partnership Attributes, Communication. Strategic Management Journal, 15(2). ABI/INFORM Global pg. 135.https://doi.org/10.1002/smj.4250150205.

Moorman, C., Deshpande, R., \& Zaltman, G. (1993). Factors affecting trust in market research relationships. Journal of Marketing, 57(1), 81-101.

Morgan, R. M., \& Hunt, S. D. (1994). The commitment-trust theory of relationship marketing. Journal of Marketing, 58(3), $20-38$. doi: $10.1177 / 002224299405800302$

Mulford, C. L., \& Rogers, D. L. (1982). Definitions and models. Interorganizational coordination: Theory, research and implementation, 9-31.

Narus, J. \& Anderson, J. (1987). Distributor contributions to partnerships with manufacturers. Business Horizons. 30(5), $34-42$. https://doi.org/10.1016/0007-6813(87)90077-2

Ngai, P., \& Huilin, L. (2010). Unfinished proletarianization: Self, anger, and class action among the second generation of peasant-workers in present-day China. Modern China, 36(5), 493-519.

Olson, E. M., Slater, S. F., \& Hult, G. T. M. (2005). The performance implications of fit among business strategy, marketing organization structure, and strategic behavior. Journal of Marketing, 69(3), 49-65.

Osborne, J. W., \& Costello, A. B. (2004). Sample size and subject to item ratio in principal components analysis. Practical Assessment, Research, and Evaluation, 9(1), 11.

Pallant, J. (2020). SPSS survival manual: A step by step guide to data analysis using IBM SPSS. Routledge.

Palmatier, R. W. (2008). Relationship marketing. Cambridge, MA: Marketing Science Institute.

Palmatier, R. W., Dant, R. P., \& Grewal, D. (2007). A comparative longitudinal analysis of theoretical perspectives of interorganizational relationship performance. Journal of Marketing, 71(4), 172-194.

Palmatier, R. W., Dant, R. P., Grewal, D., \& Evans, K. R. (2006). Factors Influencing the Effectiveness of Relationship Marketing: A MetaAnalysis. Journal of Marketing, 70(4),

Parasuraman, A., Berry, L. L., \& Zeithaml, V. A. (1991). Perceived service quality as a customer-based performance measure: An empirical examination of organizational barriers using an extended service quality model. Human Resource Management, 30(3), 335-364.

Paul, T.(1988). Relationship marketing for healthcare providers. Journal of Health Care Marketing, 8 (September), 20-25.

Payne, A., \& Frow, P. (2017). Relationship marketing: Looking backwards towards the future. Journal of Services Marketing, 31(1), 1115.

Reinalda, B. (2009). Routledge History of International Organizations: From 1815 to the Present Day. London: Routledge.

Rich, A. (2003). Notes towards a politics of location. Feminist postcolonial theory: A reader, 29-42.

Rockart, S., \& Mitchell, W. (2009). High point or hobgoblin? Consistency and performance in organizations. Working paper.

Sarkar, M. B., Echambadi, R., Cavusgil, S. T., \& Aulakh, P. S. (2001). The influence of complementarity, compatibility, and relationship capital on alliance performance. Journal of the Academy of Marketing Science, 29(4), 358-373.

Scanzoni, J. (1979). Social processes and power in families. Contemporary theories about the family: research-based theories/edited by Wesley R. Burr... [et al.].

Schreiner, M., Kale, P., \& Corsten, D. (2009). What really is alliance management capability and how does it impact alliance outcomes and success? Strategic Management Journal, 30(13), 1395-1419.

Scott, W. R., \& Davis, G. F. (2015). Organizations and organizing: Rational, natural and open systems perspectives. Routledge.

Shah, R., Hurley, C. K., \& Posch, P. E. (2006). A molecular mechanism for the differential regulation of TGF-B1 expression due to the common SNP- 509C-T (c.- 1347C> T). Human genetics, 120(4), 461-469.

Simon, H. A. (2013). Administrative behavior. Simon and Schuster.

Srinivasan, R., \& Moorman, C. (2005), Strategic firm commitments and rewards for customer relationship management in online retailing. Journal of Marketing, 69 (October), 193-200.

Stern, L. W., \& El-Ansary, A. I. (1992). Marketing channels. Englewood Cliffs.

Tadajewski, M., \& Saren, M. (2009). Rethinking the emergence of relationship marketing. Journal of Macromarketing, 29(2), $193-206$.

Tourism Industry in Vietnam. (2016). ANT Consulting Co. (https://www.antconsult.vn/news/tourism-industry-in-vietnam.html) (Accessed on 8 April, 2019).

Tsai, H. M. T., \& Chen, X. X. (2012, June). The effect of inter-organizational relationship learning on innovative advertising performance. In 2012 IEEE International Conference on Management of Innovation \& Technology (ICMIT) (pp. 279-284). IEEE.

Van de Ven, A. H., \& Ferry, D. L. (1980). Measuring and assessing organizations.

Van de Ven, A. H. (1976). On the nature, formation, and maintenance of relations among organizations. Academy of Management Review, $1(4), 24-36$

Varwick, J., \& Koops, J. (2009). The European Union and NATO: 'shrewd inter-organizationalism'in the making?. In the European Union and international organizations (pp. 115-144). Routledge.

Vietnam's Tourism Industry Continues its Growth. (2018). Vietnam Briefing. Retrieved from https://www.vietnam briefing.com/news/vietnams-tourism-industry-continues-growth-2018.html/.

Vietnam National Administration of Tourism - Ministry of Culture, Sports \& Tourism, (2020). Vietnam Tourism Annual Report 2019 released. Retrieved from https://vietnamtourism.gov.vn/english/index.php/items/15251.

Vlaar, P. W., Van den Bosch, F. A., \& Volberda, H. W. (2006). Coping with problems of understanding in inter-organizational relationships: Using formalization as a means to make sense. Organization Studies, 27(11), 1617-1638.

Waddock, S.A. (1988) Building successful social partnerships. Sloan Management Review 17 (Summer), 17-23.

Zaheer, A., McEvily, B., \& Perrone, V. (1998). Does trust matter? Exploring the effects of inter-organizational and interpersonal trust on performance. Organization Science, 9(2), 141-159.

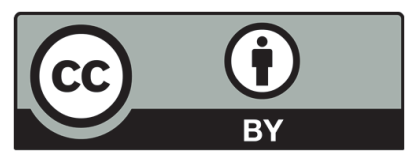

(C) 2021 by the authors; licensee Growing Science, Canada. This is an open access article distributed under the terms and conditions of the Creative Commons Attribution (CC-BY) license (http://creativecommons.org/licenses/by/4.0/). 